\title{
Forensic Evaluation and Population data of 11 Y-STRs in Moroccan im- migrants in Belgium
}

\author{
G. Mertens*, S. Rand, E. Jehaes, G. Leijnen, W. Jacobs and E. Van Marck \\ Forensic DNA Laboratory, Antwerp University Hospital, University of Antwerp, Wilrijkstraat 10, B-2650 Edegem, \\ Belgium
}

\begin{abstract}
Aim: To establish a database of Y chromosomal haplotypes of the Moroccan immigrant population of Belgium.
Methods: A sample of 109 random Moroccan male immigrants bearing different surnames and living in Belgium were typed for the 11 Y chromosome short tandem repeats DYS19, DYS385a-b, DYS389I, DYS389II, DYS390, DYS391, DYS392, DYS393, DYS438, DYS439 and DYS437.

Results: A total of 58 different haplotypes were observed. Among these, 44 were unique, 11 occurred twice, 2 were counted 4 times and 1 was observed in - surprisingly - 35 males. The resulting haplotype diversity was 0.8942 and the discrimination capacity was 0.5321 .

Conclusion: The most frequent haplotype is common in North Africa and the even higher frequency in this sample is suggestive of a founder effect of this migrant population, combined with endogamy and inbreeding.
\end{abstract}

\section{INTRODUCTION}

The use of Y chromosome specific short tandem repeats (STRs) in population and forensic genetics has proved to be an important tool in answering some specific questions [1]. In the forensic field, these markers are especially helpful in deficient paternities and rape cases [2]. With the increased use of these markers, databases have been produced permitting haplotype frequency estimation and direct application for match probability calculations in forensic studies [3].

The aim of this study was to establish a database of YSTRs for the Moroccan population of Belgium.

As a consequence of immigration starting in the 1960s, about 220, 000 people of Moroccan origin presently reside in Belgium, including those who have acquired Belgian nationality. Most Moroccan immigrants in Belgium as well as the Netherlands and Germany, belong to the Berber (Imazighen) ethnic group and originate from the Rif area, a mountainous region of northern Morocco. They make up the largest fraction $(55 \%)$ of the non-European Union foreigners living in Belgium (total population 10.4 million) [4, 5].

We thus performed a population genetic study on $11 \mathrm{Y}$ chromosome STRs, including the loci defined as the European minimal haplotype [6] (DYS19, DYS385 a-b, DYS 389I, DYS389II, DYS390, DYS391, DYS392 and DYS393), plus 2 loci (DYS438 and DYS439) added to this panel by the SWGDAM [7], and the locus DYS437.

\section{MATERIAL AND METHODS}

As a whole, the study was performed according to the guidelines on publication of population data of human polymorphisms [8].

*Address correspondence to this author at the Forensic DNA Laboratory, Antwerp University Hospital, University of Antwerp, Wilrijkstraat 10, B2650 Edegem, Belgium; Tel: +31 382139 46;

E-mail: gerhard.mertens@uza.be
Buccal swabs were collected from 109 Moroccan males, representing the alleged fathers from paternity cases. All had consented to - anonymously - use their data in a population genetic study. DNA was extracted using the Qiamp DNA kit (Qiagen, Venlo, Netherlands) [9]. DNA was amplified in a GeneAmp 9700 Thermal Cycler (Applied Biosystems, Foster City, CA) using the Power Plex ${ }^{\circledR} \mathrm{Y}$ (Promega, Madison, WI) multiplex [10], according to the manufacturer's instructions. PCR products were subsequently analysed by capillary electrophoresis on an ABI 3100 Genetic Analyzer (Applied Biosystems, Foster City, CA). Alleles were named according to the last recommendation of the DNA Commission of the International Society for Forensic Genetics [11].

Haplotype diversity was estimated by applying Nei's [12] formula: $\mathrm{HD}=\left(1-\sum \mathrm{f}_{\mathrm{i}}^{2}\right)(\mathrm{n} / \mathrm{n}-1)$, where $\mathrm{n}$ is the sample size and $\mathrm{f}_{\mathrm{i}}$ is the haplotype frequency. For the calculation, the loci DYS385a-b were excluded due to the impossibility of assigning each allele to one or the other locus of this ambiguous system.

Gene diversity was calculated as GD $=1-\sum \mathrm{p}_{\mathrm{i}}^{2}$ with $\mathrm{p}_{\mathrm{i}}$ being the allelic frequency [13].

The discrimination capacity (DC) was determined as the proportion of different haplotypes [14] and is obtained by dividing the number of different haplotypes by the number of individuals in the sample.

Allelic frequencies were counted and their errors estimated using the Arlequin software [15].

\section{RESULTS AND DISCUSSION}

Table 1 contains the allele frequencies for $11 \mathrm{Y}$ chromosomal STRs in the sample of 109 Moroccan male immigrants in Belgium with different surnames. Fig. (1) shows these frequencies (green bars) next to data from also Berberspeaking residents of Morocco. The purple bars refer to the study $(\mathrm{n}=49)$ by Quintana-Murci et al. [16] on 8 of the 11 
Table 1. Allele Frequencies at 11 Y-STRs in a Population of Moroccan Immigrants in Belgium $(\mathbf{n}=109)$

\begin{tabular}{|c|c|c|c|c|c|}
\hline \multicolumn{2}{|c|}{ DYS385a-b } & \multicolumn{2}{|c|}{ DYS19 } & \multicolumn{2}{|c|}{ DYS389I } \\
\hline Haplotype & Frequency $( \pm$ SD) & Allele & Frequency $( \pm$ SD) & Allele & Frequency $( \pm$ SD $)$ \\
\hline $11-13.2$ & $0.028+0.016$ & 13 & $0.725 \pm 0.043$ & 12 & $0.147 \pm 0.034$ \\
\hline $12-14$ & $0.018 \pm 0.013$ & 14 & $0.147 \pm 0.034$ & 13 & $0.128 \pm 0.032$ \\
\hline $13-13$ & $0.018 \pm 0.013$ & 15 & $0.101 \pm 0.029$ & 14 & $0.688 \pm 0.046$ \\
\hline $13-14$ & $0.459 \pm 0.048$ & 16 & $0.028 \pm 0.016$ & 15 & $0.028 \pm 0.016$ \\
\hline $13-15$ & $0.101 \pm 0.029$ & & & 16 & $0.009 \pm 0.009$ \\
\hline $14-14$ & $0.101 \pm 0.029$ & \multicolumn{2}{|c|}{ DYS389II } & \multicolumn{2}{|c|}{ DYS390 } \\
\hline $14-15$ & $0.055 \pm 0.022$ & Allele & Frequency $( \pm$ SD) & Allele & Frequency $( \pm$ SD $)$ \\
\hline $15-16$ & $0.027 \pm 0.016$ & 28 & $0.083 \pm 0.027$ & 22 & $0.119 \pm 0.031$ \\
\hline $16-19$ & $0.009 \pm 0.009$ & 29 & $0.101 \pm 0.029$ & 23 & $0.119 \pm 0.031$ \\
\hline $17-17$ & $0.009 \pm 0.009$ & 30 & $0.651 \pm 0.046$ & 24 & $0.725 \pm 0.043$ \\
\hline $17-18$ & $0.046 \pm 0.020$ & 31 & $0.147 \pm 0.034$ & 25 & $0.028 \pm 0.016$ \\
\hline $12-18$ & $0.009 \pm 0.009$ & 32 & $0.009 \pm 0.009$ & 26 & $0.009 \pm 0.009$ \\
\hline $13-18$ & $0.009 \pm 0.009$ & 33 & $0.009 \pm 0.009$ & & \\
\hline $13-19$ & $0.037 \pm 0.018$ & \multicolumn{2}{|c|}{ DYS391 } & \multicolumn{2}{|c|}{ DYS392 } \\
\hline $14-16$ & $0.018 \pm 0.013$ & Allele & Frequency $( \pm \mathrm{SD})$ & Allele & Frequency $( \pm \mathrm{SD})$ \\
\hline $14-17$ & $0.009 \pm 0.009$ & 9 & $0.624 \pm 0.047$ & 10 & $0.009 \pm 0.009$ \\
\hline $16-16$ & $0.009 \pm 0.009$ & 10 & $0.284 \pm 0.043$ & 11 & $0.899 \pm 0.029$ \\
\hline $16-17$ & $0.009 \pm 0.009$ & 11 & $0.074 \pm 0.025$ & 12 & $0.018 \pm 0.013$ \\
\hline $13-16$ & $0.009 \pm 0.009$ & 12 & $0.018 \pm 0.013$ & 13 & $0.055 \pm 0.022$ \\
\hline $15-15$ & $0.009 \pm 0.009$ & & & 15 & $0.018 \pm 0.013$ \\
\hline \multirow[t]{13}{*}{$13-21$} & $0.009 \pm 0.009$ & DYS393 & & DYS437 & \\
\hline & & Allele & Frequency $( \pm \mathrm{SD})$ & Allele & Frequency $( \pm \mathrm{SD})$ \\
\hline & & 10 & $0.009 \pm 0.009$ & 14 & $0.890 \pm 0.030$ \\
\hline & & 12 & $0.138 \pm 0.033$ & 15 & $0.073 \pm 0.025$ \\
\hline & & 13 & $0.789 \pm 0.039$ & 16 & $0.028 \pm 0.016$ \\
\hline & & 14 & $0.046 \pm 0.020$ & 17 & $0.009 \pm 0.009$ \\
\hline & & 15 & $0.018 \pm 0.013$ & & \\
\hline & & DYS438 & & DYS439 & \\
\hline & & Allele & Frequency $( \pm$ SD) & Allele & Frequency $( \pm \mathrm{SD})$ \\
\hline & & 9 & $0.073 \pm 0.025$ & 10 & $0.679 \pm 0.045$ \\
\hline & & 10 & $0.780 \pm 0.040$ & 11 & $0.202 \pm 0.039$ \\
\hline & & 11 & $0.119 \pm 0.031$ & 12 & $0.110 \pm 0.030$ \\
\hline & & 12 & $0.028 \pm 0.016$ & 13 & $0.009 \pm 0.009$ \\
\hline
\end{tabular}




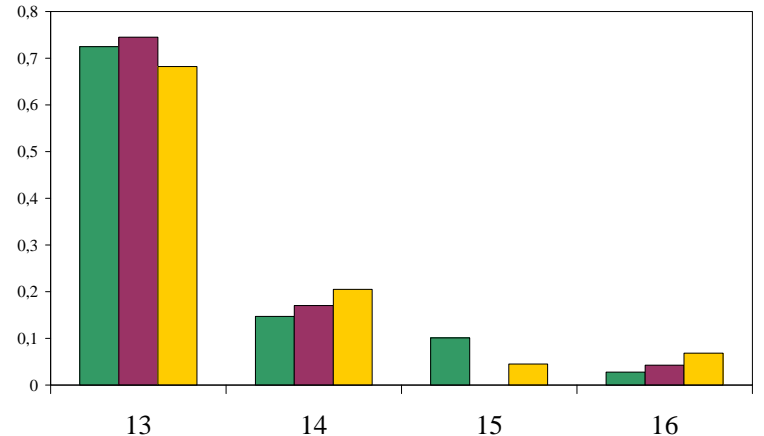

DYS19 GD $=0.442$

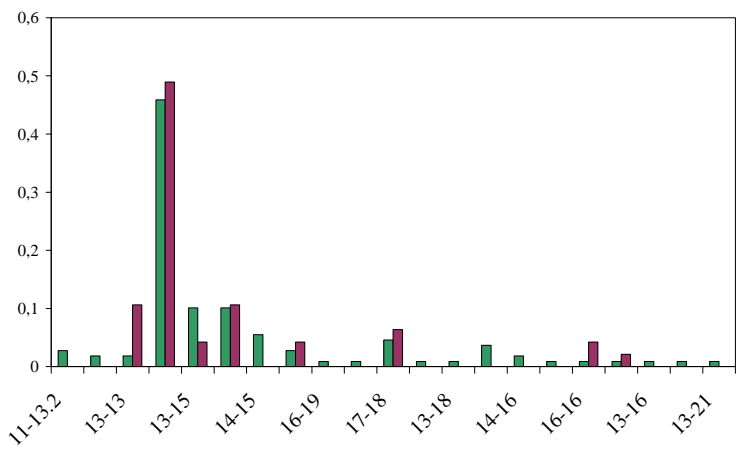

DYS385a-b GD $=0.759$
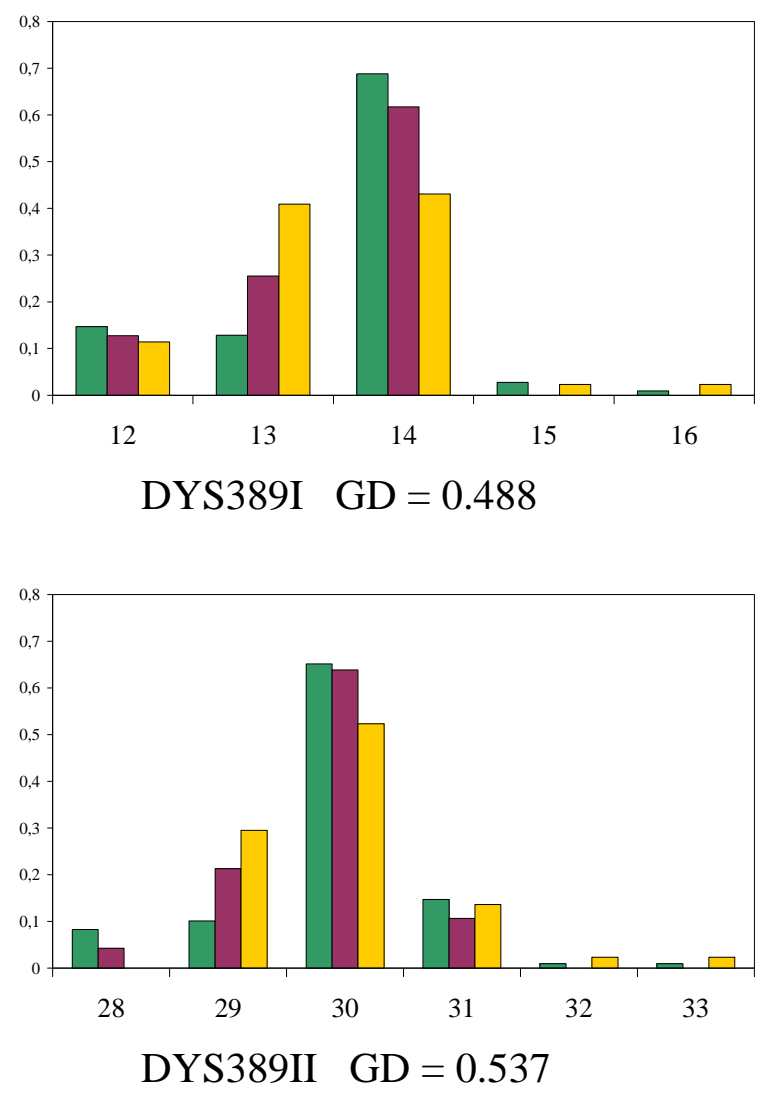
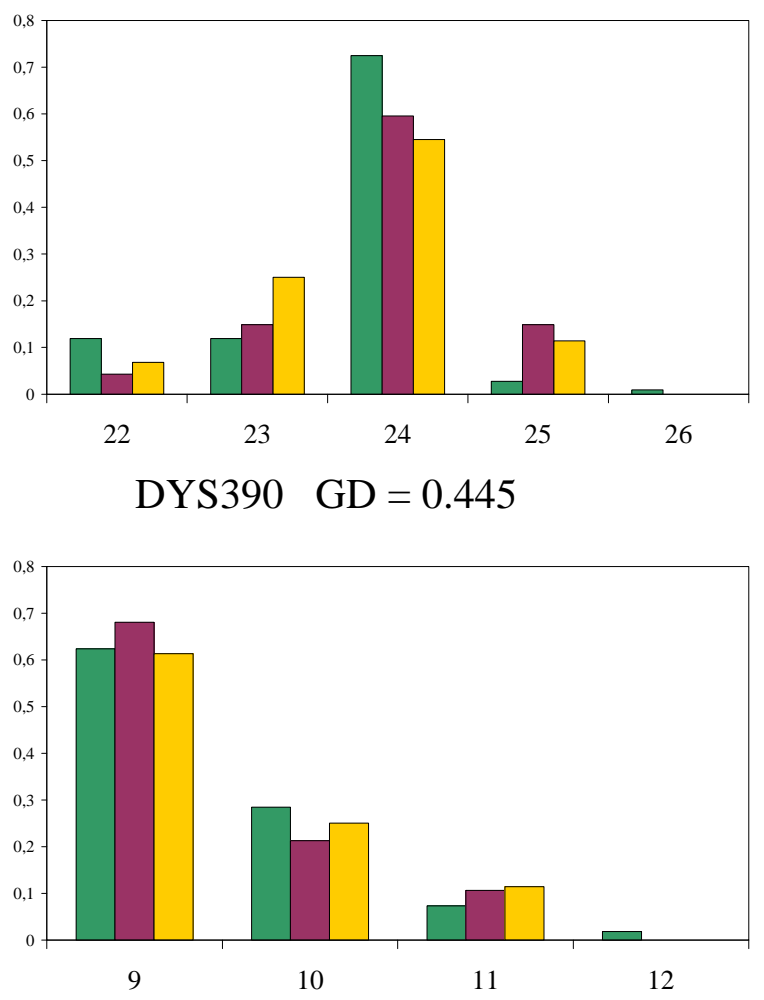

DYS391 $=0.524$
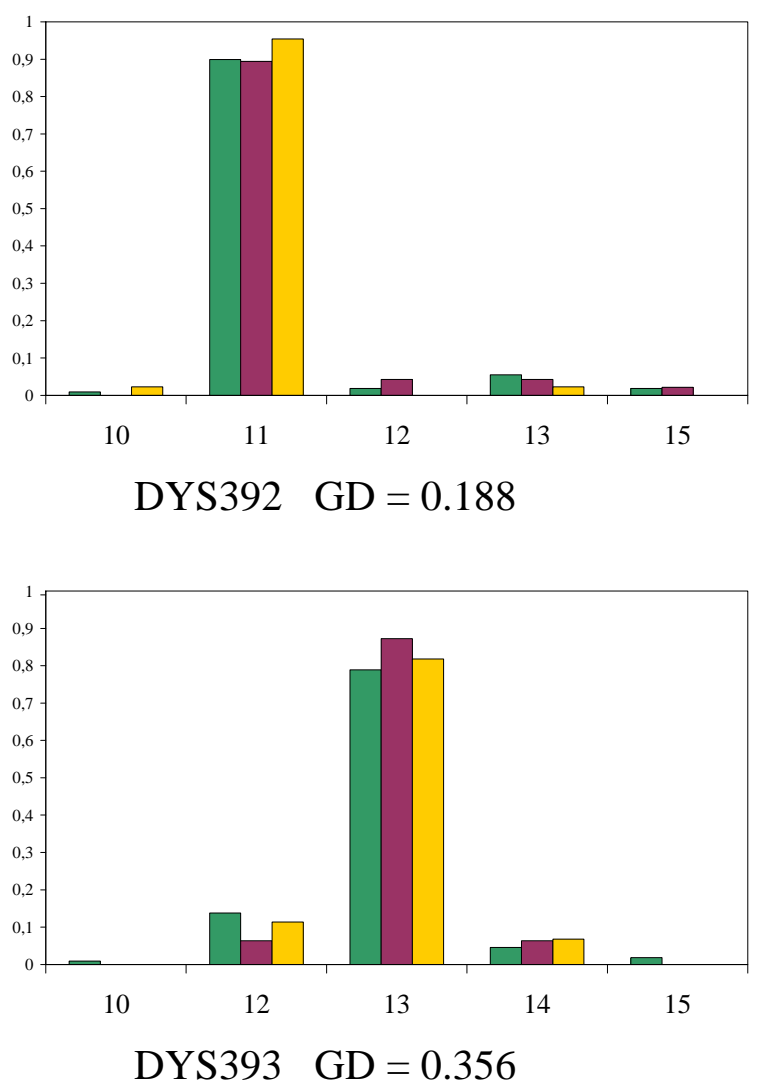

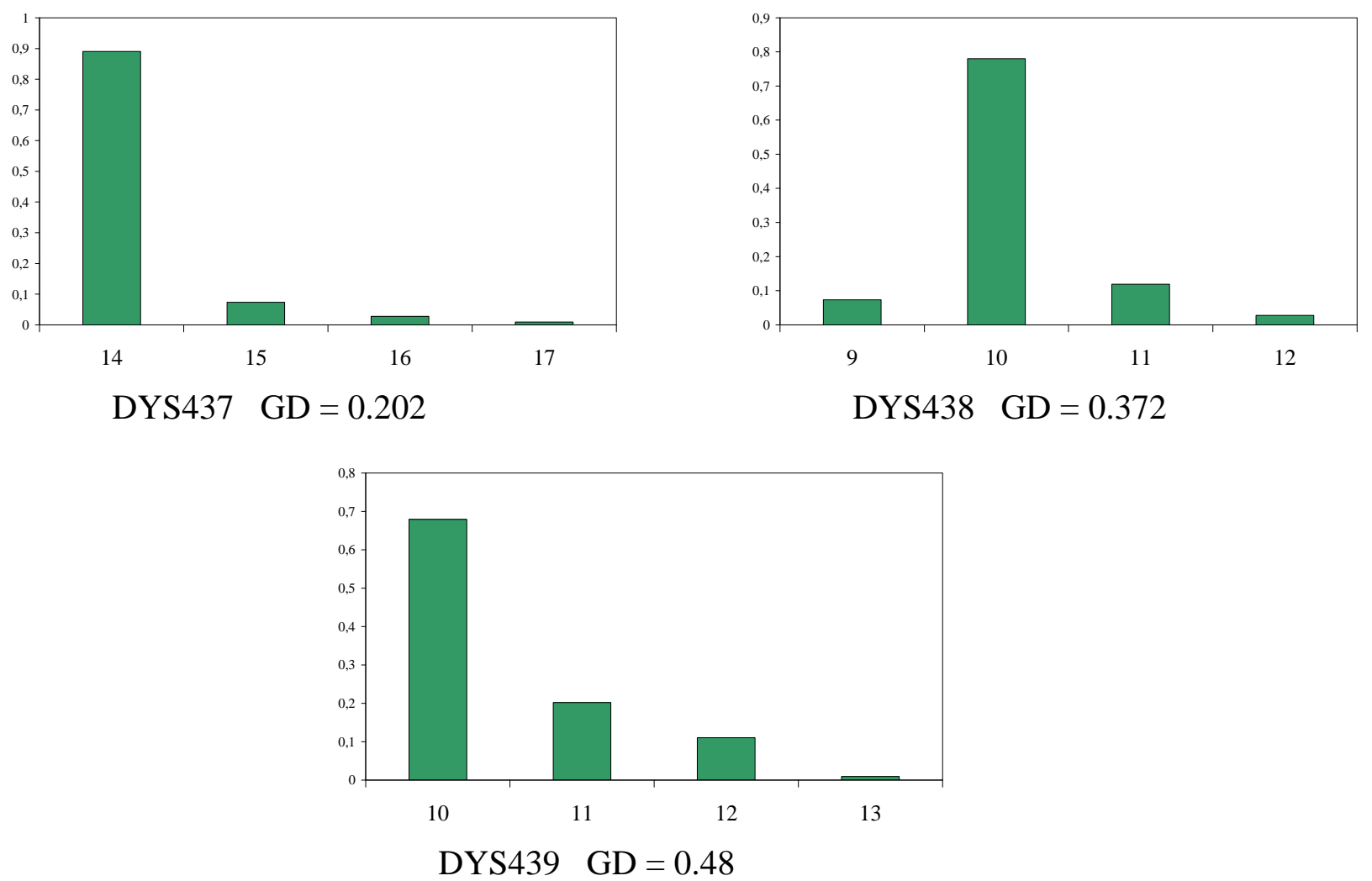

Fig. (1). Allelic frequencies for Y-STRs in three Moroccan population samples: immigants in Belgium (green), Southern Berbers (purple) and Berber-speaking Moroccans (yellow).

Y-STRs we have typed, while the yellow bars with 7 of 11 Y-STRs we tested, come from the publication by Bosch et al. [17] $(\mathrm{n}=44)$. The figure shows no major differences between the "original" Berbers and those who migrated to Belgium. The GD value below each histogram belongs to the Moroccan immigrants in Belgium.

Table 2 gives the 58 different 11-locus Y-STR haplotypes observed. Of 109 males, 44 had a unique Y-STR haplotype, 35 carried an identical haplotype (H10, see Table 2), 11 haplotypes were shared among two males and 2 haplotypes were observed among 4 seemingly unrelated males. This results in a HD of 0.8942 and a DC of 0.5321 , which implies there is only a chance of about 1 in 2 to distinguish 2 random men with these 11-locus haplotypes. This seriously precludes the ability of a Y-STR assay to resolve two male samples from the Moroccan immigrant population of Belgium. Whether typing for a few more Y-STRs would solve the problem, is questionable. Indeed, since this population seems strongly related we assume that our results reflect largely identical Y chromosomal haplotypes. It should be stressed that for practical forensic and paternity casework only mismatching Y chromosomal haplotypes will have statistical relevance in this population.

The observed data can be explained by a combination of endogamy, inbreeding and a founder effect. First, the most frequently observed haplotype (H10) is relatively common in Northern Africa. Though exact comparison is not possible since not exactly the same Y-STRs were used in different studies, the haplotype H10 seems the most frequent haplotype in Moroccan Berber as well as Arab-speaking populations. The haplotype $13 ; 13-14 ; 14 ; 30 ; 24 ; 9 ; 11 ; 13$ for the YSTRs DYS19;DYS385a-b;DYS389I,DYS389II;DYS390;
DYS391;DYS392;DYS393 was observed in 7 out of 44 (16\%) and 5 out of $49(10 \%)$ Moroccan Berbers and 12 out of $44(27 \%)$ and 12 out of 60 (20\%) Moroccan Arabs by Bosch et al. [16] and Quintana-Murci et al. [17], respectively. Searching the Y chromosome haplotype reference database (YHRD), which contains 25, 576 haplotypes typed for the same Y-STRs we have tested - excluding DYS437 from 477 populations (Release 23 from 15-01-2008), yielded 141 matches for the H10 haplotype (minus DYS437) [18]. The highest frequency of this haplotype is found in Tunisia, with 31 out of 246 summed for 3 Tunisian populations, including Zribia, where the haplotype has a frequency of 19/31 [19]. Still, the YHRD does not contain any data on Morocco. We thus infer that the region where most Moroccan immigrants in Belgium come from, has a high frequency of the haplotype and can be considered a "founding region". Furthermore, the practice of endogamous marriage is highly popular in this population. The percentage of Belgian Moroccans marrying a partner coming directly from Morocco has increased from $40 \%$ in 1979 to $65 \%$ in 2007 [20]. Finally, the frequency of shared genes may be further increased in this population because of inbreeding. According to sociological studies, in many Islamic countries consanguinity is common, ranging between 20 and $30 \%$ in Morocco [21]. In addition, consanguineous marriages are often cross-border marriages and thus intimately linked to the facilitation of the immigration procedure. While the number of marriages with friends of the family is decreasing, the number of biological kin marriages is increasing in Moroccans [22]. Finally, marriages between cousins are currently much more prevalent among the lower social classes in the Arab world [23], who are also the major category migrating to 
Table 2. Haplotypes of 11 Y-STR Loci in a Sample of 109 Moroccan Males

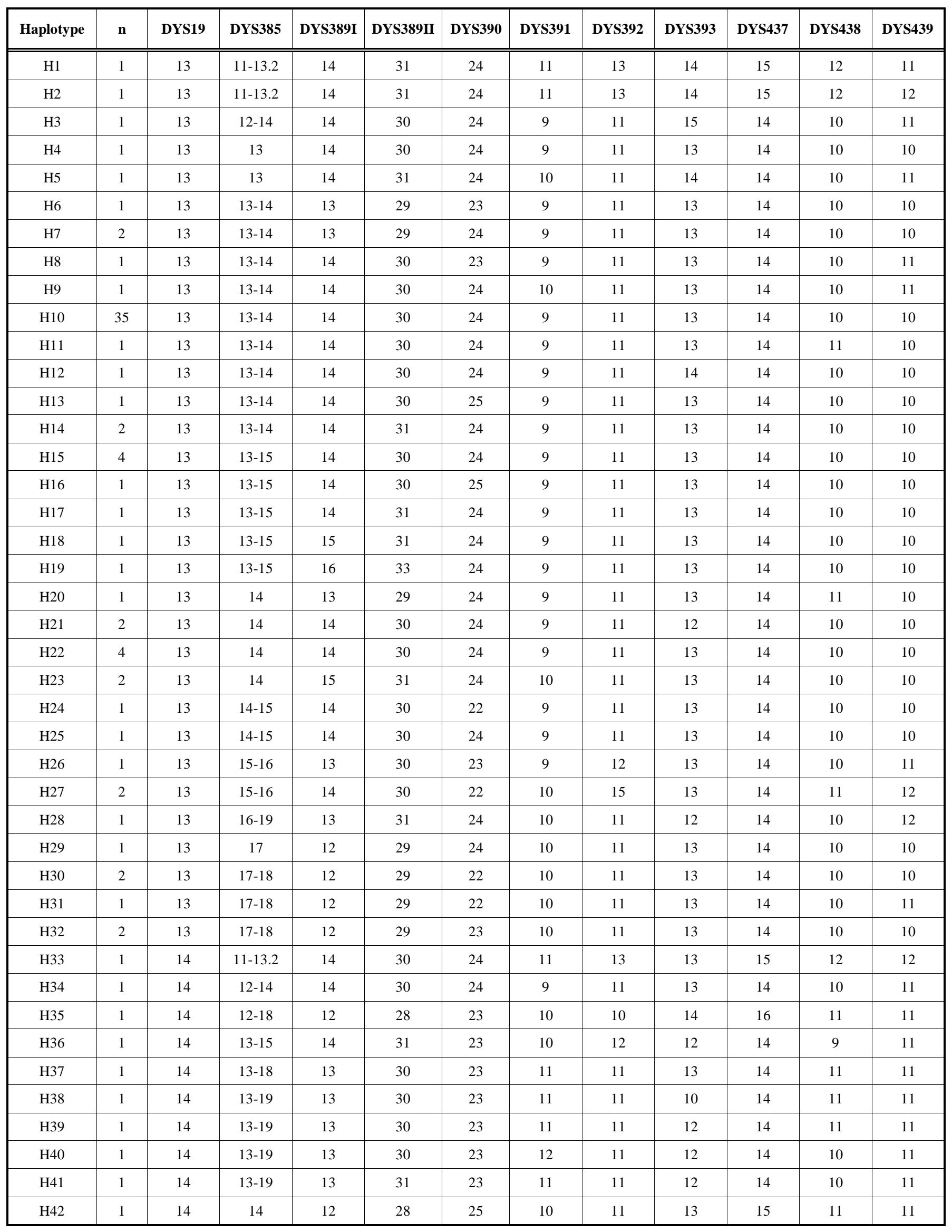


(Table 2). Contd.....

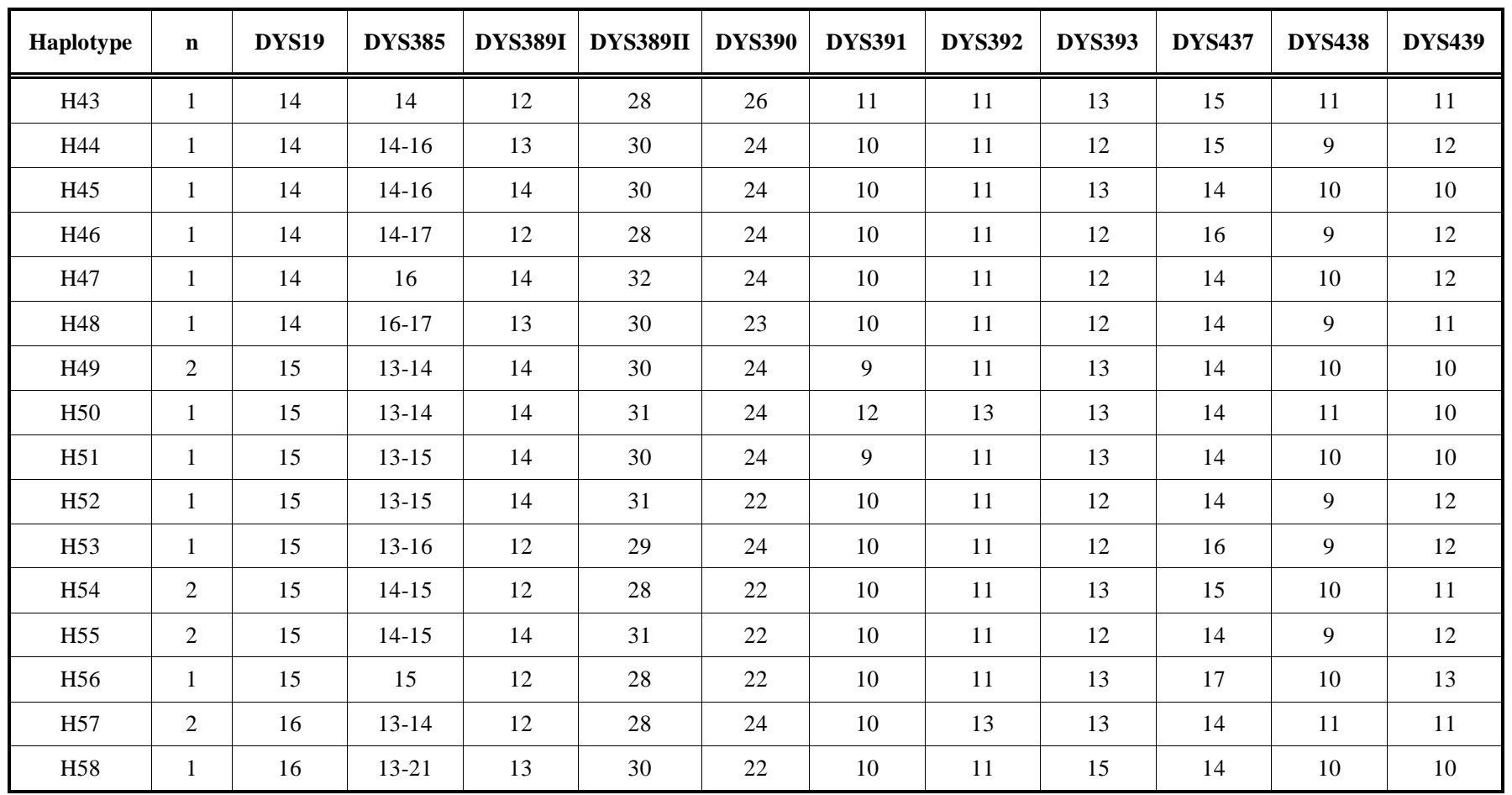

Haplotype diversity: 0.8942 - Discrimination capacity: 0.5321.

western Europe. That the high frequency of one haplotype is also related to consanguinity is supported by medical data. Indeed, in the Netherlands a five times higher proportion of hereditary causes of death are reported for the Moroccan immigrant population compared to the indigenous population. This is explained by a high inbreeding coefficient [24].

Last but not least, the high coancestry also has implications for the interpretation of forensic DNA evidence such as the calculation of defendant - crime scene DNA identity probability. The NRC formula incorporates the factor "theta" as a coancestry coefficient, the magnitude of which clearly influences the conditional probability that a "matching DNA-profile" between crime related biological stain and suspect originated from the suspect [25]. Thus, the observed data on Y chromosomal STR loci may also have implications for calculations using autosomal STRs.

\section{REFERENCES}

[1] Jobling, M.A.; Pandya, A.; Tyler-Smith, C. Int. J. Legal Med., 1997, 110, 118-124.

[2] Prinz, M.; Boll, K.; Baum, H; Shaler, B. Forensic Sci. Int., 1997, 85, 209-218.

[3] Roewer, L.; Krawczak, M.; Willuweit, S.; Nagy, M.; Alves, C.; Amorim, A.; Anslinger, K.; Augustin, C.; Betz, A.; Bosch, E.; Cagliá, A.; Carracedo, A.; Corach, D.; Dekairelle, A.F.; Dobosz, T.; Dupuy, B.M.; Füredi, S.; Gehrig, C.; Gusmaõ, L.; Henke, J.; Henke, L.; Hidding, M.; Hohoff, C.; Hoste, B.; Jobling, M.A.; Kärgel, H.J.; de Knijff, P.; Lessig, R.; Liebeherr, E.; Lorente, M.; Martínez-Jarreta, B.; Nievas, P.; Nowak, M.; Parson, W.; Pascali, V.L.; Penacino, G.; Ploski, R.; Rolf, B.; Sala, A.; Schmidt, U.; Schmitt, C.; Schneider, P.M.; Szibor, R.; Teifel-Greding, J.; Kayser, M. Forensic Sci. Int., 2001, 118, 106-113.

[4] Eggerickx, T.; Kesteloot, C.; Poulain, M. The foreign population of Belgium. National Institute of Statistics: Brussels, 2002

[5] Perrin, N. The twenty most important foreign population groups in Belgium. National Institute of Statistics: Brussels, 2002.
Gill, P.; Brenner, C.; Brinkmann, B.; Budowle, B.; Carracedo, A.; Jobling, M.A.; de Knijff, P.; Kayser, M.; Krawczak, M.; Mayr, W.R.; Morling, N.; Olaisen, B.; Pascali, V.; Prinz, M.; Roewer, L.; Schneider, P.M.; Sajantila, A.; Tyler-Smith, C. Int. J. Legal Med., 2001, 114, 305-309.

[7] Lee, D.; Sims, G.; Newman, J.; Laad, C.; Smerick, S.; Barna, C.; Gross, A. For. Sci. Comm., 2004, 6, 3

[8] Lincoln, P.; Carracedo, A. Forensic Sci. Int., 2000, 110, 3-5.

[9] Greenspoon, S.A.; Scarpetta, M.A.; Drayton, M.L.; Turek, S.A. QIAamp spin columns as a method of DNA isolation for forensic casework. J. Forensic Sci., 1998, 43, 1024-1030.

[10] Krenke, B.E.; Viculis, L.; Richard, M.L. Forensic Sci. Int., 2005 , $148,1-14$

[11] Gusmão, L.; Butler, J.M.; Carracedo, A.; Gill P; Kayser, M.; Mayr, W.R.; Morling, N.; Prinz, M.; Roewer, L.; Tyler-Smith, C.; Schneider, P.M. Int. J. Legal Med., 2006, 120, 191-200.

[12] Nei, M. Molecular evolutionary genetics. Columbia University Press: New York, 1987

[13] Shete, S. J. Heredity, 2003, 94, 421-424.

[14] Kayser, M.; Caglia, A.; Corach, D. Int. J. Legal Med., 1997, 110, 125-133.

[15] Excoffier, L.; Laval, G.; Schneider, S. Evol. Bioinform. Online, 2005, $1,47-50$

[16] Quinatana-Murci, L.; Bigham, A.; Rouba, H.; Barakat, A.; McElreavy, K.; Hammer, M. Forensic Sci. Int., 2004, 140, 113-115.

[17] Bosch, E.; Calafell, F.; Pérez-Lezaun, A.; Comas, D.; Izaabel, H.; Akhayat, O.; Sefiani, A.; Hariti, G.; Dugoujon, J.M.; Bertranpetit, J. Int. J. Legal Med., 2000, 114, 36-40.

[18] Willuweit, S.; Roewer, L. For. Sci. Int. Genetics, 2007, 1, 83-87.

[19] Cherni, L.; Pereira, L.; Goios, A.; Loueslati, B.Y.; Khodjet el Khil, H.; Gomes, I.; Gusmão, L.; Alves, C.; Slama, A.; Amorim, A.; Elgaaied, A.B. Forensic Sci. Int., 2005, 152, 95-99.

[20] Lodewyckx, I.; Geets, J.; Timmerman, C. Aspecten van Marokkaanse huwelijksmigratie en Marokkaans familierecht. Centre for Migration and Intercultural Studies (CeMIS): Antwerp, 2007

[21] Dutch Central Bureau of Statistics (CBS). Mortality; causes of death; age and gender between 1980 and 1996. CBS: Voorburg, 1997

[22] Reyniers, G. J. Comp. Family Studies, 2001, 32, 1-22. 
[23] Khlat, M. Endogamy in the Arab world. In: Genetic disorders among Arab populations; Teebi, A.S.; Farg, T.I. Eds.; Oxford University Press: Oxford, 1997; pp. 63-80.

[24] Schulpen, T.; van Wieringen, J.; van Brummen, P.J.; van Riel, J.M.; Beemer, F.A.; Westers, P.; Huber, J. Eur. J. Public Health, 2005, 16, 290-293.
[25] National Research Council. The evaluation of forensic DNA evidence. National Academy Press: Washington DC, 1996; pp. 125165 .

Received: January 30, 2008

(C) Mertens et al.; Licensee Bentham Open.

This is an open access article distributed under the terms of the Creative Commons Attribution License (http://creativecommons.org/licenses/by/2.5/), which permits unrestrictive use, distribution, and reproduction in any medium, provided the original work is properly cited. 